\title{
CNRS weakened by uncertainty but back in business
}

\section{Paris}

A SECTION of a bill passed in a late-night sitting of the Assemblée Nationale (the French lower house) on 12 June looks set to bring to an end a legal imbroglio that has paralysed the normal functioning of the main French research council, the Centre Nationale de la Recherche Scientifique (CNRS), for the past twelve months. The bill, due for Senate approval next week, will retrospectively validate the vital CNRS appointment committees declared unconstitutional last spring (Nature 324, 9; 1987).

High court rulings earlier this year ended the worries of many newly recruited researchers who had found their jobs under threat when the CNRS appointment committees - the Comité National - were suddenly dissolved. But uncertainties remained for new appointees in the life sciences (see Nature $\mathbf{3 2 6}$, $120 ; 1987)$. Measures in the new bill will remove this anomaly and allow promotions of senior scientists in all disciplines, also blocked by the dispute, to go ahead.

The root of the quarrel lay in Article 6 of a decree, drawn up under President Mitterrand's socialist government in 1982 , that introduced a system of proportional representation in the election of Comité National members by CNRS staff. Back in 1983, the conservative Fédération des Syndicats Autonomes, the trade union representing medical lecturers and lawyers, questioned the legality of Article 6. But before the problem was finally resolved the socialist government found itself out of office.

The new right-wing government, elected in 1986, objected to what it saw as the excessive influence of the left-wing trade unions representing researchers. A little over half of the 990 members of the Comité National, which both appoints juries to select new recruits and decides on senior promotions and performance, is nominated by the unions representing CNRS researchers and university staff. Although the remainder of members are appointed by the government, union influence has been strong enough to oppose government reforms which would have reduced the separation of teaching and research and increased industry's responsibility for research.

When a right-wing trade union, the Syndicat Autonome d'Enseigennants Médecine, managed in March 1986 to obtain a ruling by the High Court (Conseil d'Etat) declaring illegal the 1983 elections to the life sciences section of the Comité National, the new government saw its chance to act. The science minister, Alain Devaquet, abolished the entire com- mittee, freezing new appointments and postponing the promotion of senior scientists.

A temporary measure gave two-thirds of the new recruits one-year contracts while the constitution of the Comite National was being amended. But the 285 scientists affected were not satisfied and formed a pressure group, the Collectif des Admissables, to lobby for ratification of their posts and to join with unions to put their case before the High Court. Meanwhile Devaquet fell victim to his right-wing policies. When students took to the streets of Paris to protest against education reform he was forced to resign. A new minister, Jacques Valade, was appointed in January 1987. High Court rulings then gave both victory and defeat to the Collectif des Admissables. The court ruled that Devaquet had acted illegally in abolishing the Comité National, thus opening the way for recruiting to proceed, but confirmed its earlier decision that elections in the life science section of the Comité National were invalid. Life scientists were thus left in limbo. Promotions of senior scientists were also in disarray because the Comité National had not completed its decisions before its demise.

Only after the Senate approves the new bill will everything return to normal (if time can be found for the bill before the summer recess in July). But the question still remains of why the mess was not sorted out earlier. According to Paul Janiaud, leader of one union representing researchers, the Syndicat National des Chercheurs Scientifiques, the government wished to exploit the chaos within CNRS to weaken opposition to reforms.

The government has cut grants to laboratories by 15-20 per cent, and changed the constitution of the CNRS to provide for increased representation of teachers in its electorate and to reduce the number of elected members of the Comité National. It also aims to abolish tenured posts for young researchers and to replace them with two- or three-year postdoctoral fellowships, a policy favoured by the director-general of the CNRS, Serge Feneuille. The CNRS will find it hard to recover from disruptions to its calendar. Appointments and promotions due to be decided in June 1986 will not be finalized until the autumn. Laboratory evaluations scheduled for October will be put back until next spring. In the meantime, CNRS has to elect a new Comité National and recruit new researchers. Many prospective candidates may have been dissuaded from seeking a career in CNRS and gone into industry - but this is exactly what the government would like.

\section{Hitachi looks to UK}

HIтACHI, the Japanese electronics giant, is to create a computer software laboratory at its London headquarters to exploit the skills of the British in artificial intelligence. The programme, with an initial budget of more than $£ 1$ million, will be co-ordinated by Hitachi but at least two major contracts will be assigned, one to a university Glasgow, Strathclyde and Edinburgh are being considered - and one commercially.

Despite having 10,000 computer programmers, Hitachi believes Britain has much of the world's expertise in artificial intelligence and that the British are better suited to writing programs for the nonJapanese user.

B.J.

\section{Sir Mark's warning}

Professor Sir Mark Richmond, the new chairman of the Committee of Vice-chancellors and Principals of the Universities of the United Kingdom (CVCP), warned last

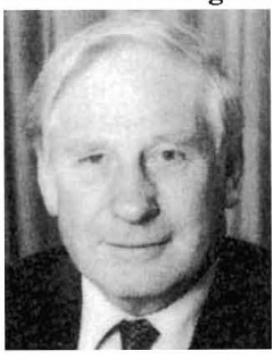
week that although government proposals to introduce a system of contract funding had positive aspects, if they were "driven very hard and in an unthinking way, everything gets into a straitjacket and there is no room to innovate". In his inaugural speech, Sir Mark said that the cutbacks in higher education since 1981 had given the system "an enormous kick up the pants" and had reminded universities that society "does not owe us a living". He described as inevitable proposals to restructure the higher education system by concentrating high-spending research in centres of excellence, but added that if such a programme were put into practice aggressively the result would be "real problems of motivation and reorganization".

S.H.

\section{AMA on AIDS tests}

The American Medical Association, the largest medical organization in the United States, seems set to oppose compulsory testing for the HIV virus which causes AIDS and to back powerful new laws designed to protect the rights of those found to be seropositive for the virus. These recommendations are in a report being presented to AMA's annual meeting this week.

The report does not raise objection to the routine testing of immigrants, military personnel and prisoners in federal jails but it rejects Reagan administration plans to test individuals considering marriage and all hospital patients on the grounds that it would be a waste of resources and would cause distress to false positives. The answer is seen in voluntary testing, carried out in complete confidentiality, with counselling for those testing positive. A.A. 